\title{
Environmental Thermal Conditions Related to Performance, Dynamics and Safety of Logging in the Brazilian Amazon
}

\author{
Kauê Augusto Oliveira-Nascimento, Niro Higuchi, Daniel DeArmond, \\ Renato Cesar Gonçalves Robert, Julio Eduardo Arce, João Paulo Fidalgo Carvalho
}

\begin{abstract}
The Amazon rainforest covers an area of about $50 \%$ of the Brazilian national territory, which consists mainly of upland rainforests that are generally poorly managed, because of low investment in technology, planning, operations and manufacturing. Logging activities require a large contingent of heavy machinery and an intense physical workload from the operators and crews. The thermal comfort at work in tropical regions is between 20 and $24^{\circ} \mathrm{C}$; however, in the Central Amazon the daily average temperature exceeds $28^{\circ} \mathrm{C}$. The sum of these adverse factors leads to a common denominator: low quality logging operations that lead to unsustainable forest management. The objective of this study was to investigate the influence of environmental thermal conditions on performance, rest breaks, work dynamics and safety of workers involved in the logging operations, as well as to better understand their interactions. The data was collected from the following logging activities: felling, pre-skidding, skidding and landing operations. These variables were analyzed using PCA analysis, MANOVA and multiple linear regression. The variables of productivity and rest breaks were strongly influenced by mechanical interruption and time of the workday. We concluded that mechanical availability was the most influential factor in the performance of logging operations. In addition, environmental thermal conditions, bonus payments and work dynamics showed an influence. To a less extent, there was an influence of safety and physical comfort of workers, which resulted in more rest breaks, depending on the operation involved. This influence was observed in operations with a higher physical workload (felling and pre-skidding). Moreover, the tree volume had a significant impact on the productivity of the chainsaw operator, which was also influenced by the species factor, as in the species Hymenolobium modestum. Lastly, improvements in working conditions such as appropriate clothing, job rotation and scheduled breaks would lead to a greater worker well-being with increased labor productivity and safety. In turn, this would greatly contribute to the quality and performance of overall forest management and sustainability in the economic development of the Amazon region.
\end{abstract}

Keywords: ergonomics, WBGT, motor-manual felling, forest management, productivity

\section{Introduction}

The Amazon rainforest covers an area of about $50 \%$ of the Brazilian national territory, which consists mainly of upland rainforests that are generally poorly managed because of low technology used in planning, operations and manufacturing. The timber industry is important for the economy of the region and has enormous potential for growth due to the large standing inventory of commercial volume (Strand et al. 2018, Ahmed and Ewers 2012, Higuchi et al. 2010). However, there are several factors that hinder sustainable forest management in the region, such as lack of human resource training, lack of »cutting edge « technology in logging (newer machinery) and in timber processing (automation and optimization in sawmills) and precarious working conditions (lack of social wellbeing or safety net programs). The sum of these factors 
leads to a common denominator: low quality logging operations that lead to unsustainable forest management (BIONTE 1997).

Currently, employment in logging is considered one of the most stressful and dangerous in the forest industry (Lilley et al. 2002, Laschi et al. 2016), being aggravated by adverse conditions specific to tropical rainforests such as diseases, hot and humid climate, difficult site accessibility, to name a few (Nascimento et al. 2017). For instance, Borz et al. (2015) found strong relations between the extraction distance and accessibility conditions and low production rates of selective logging, which demand more turns and energy spent in the operation.

Logging operations require continuous worker attention and are typically conducted in physically demanding conditions (Jourgholami et al. 2013, Cheta et al., 2018), especially in the selective logging of the tropics (Nascimento et al. 2018). The thermal comfort at work in tropical regions is between 20 and $24^{\circ} \mathrm{C}$ (Iida 1990). However, in the Central Amazon, the daytime (workday) average exceeds $28^{\circ} \mathrm{C}$ (INMET 2016). There- fore, there is a thermal discomfort during logging operations and forestry work in the region (Nascimento et al. 2017). To further aggravate this situation, the occurrence of extreme events, like the El Niño phenomena, has been causing an increase in the average temperatures of the region (Jiménez-Muñoz et al. 2013). The Brazilian regulation that determines the limit of tolerance for heat exposure at work, the Occupational Standard no 15 (Insalubrity), Annex 03 (Heat stress), was published by the Ministry of Labor in 1978. This standard stipulates the work/rest regime per hour of activity, based on physical workload and temperatures found in the work environment (Brasil 1978).

Currently, the approach to work conditions in Amazonian forests is moving towards the improvement of the well-being and performance of employees. Therefore, there is a need to identify and eliminate the critical causes of lower performance, increase the quality of work and well-being of workers. This was the justification and guiding principle for this research.

In this context, this study sought to investigate the influence of environmental thermal conditions on

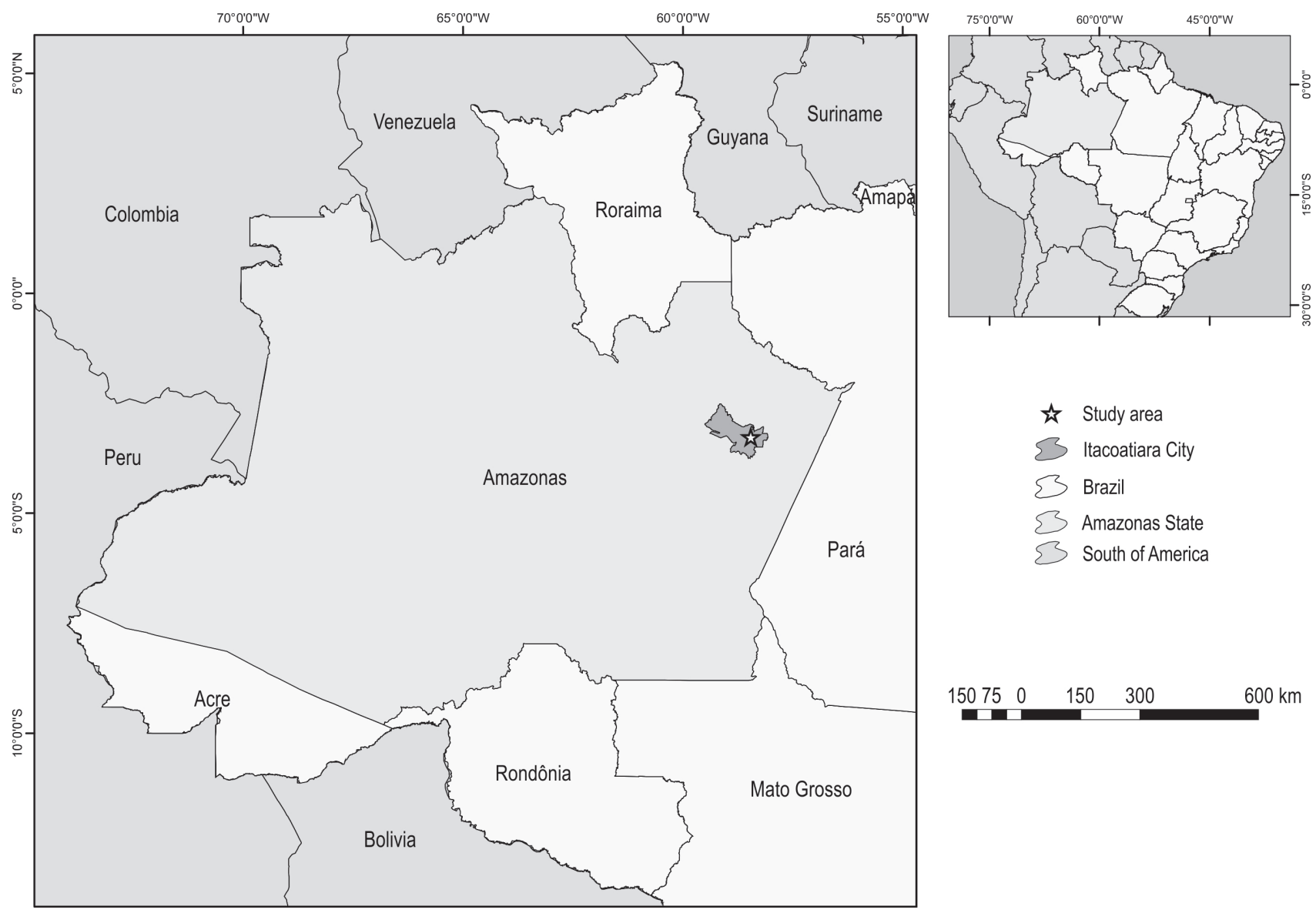

Fig. 1 Map of the state of Amazonas, with emphasis on the municipality of Itacoatiara and company's headquarters 
performance, rest breaks, work dynamics and safety of workers involved in the logging operations, as well as to improve the understanding of their interactions. Furthermore, the aim of this study was to generate industry specific knowledge that will combine the well-being of workers with an increased performance that leads to a safer and healthier work environment. This study assumed that thermal environmental conditions have a negative influence on the performance, safety and dynamics of work in logging, as well as being an important factor to be considered in the search for sustainable forest management in the Amazon.

\section{Materials and Methods}

\subsection{Study Area}

This research was conducted on the property of the industrial timber company Precious Woods Amazon, headquartered in the municipality of Itacoatiara, Central Amazon region. The company's land holdings are scattered throughout the additional municipalities of Itapiranga and Silves next to Itacoatiara, all of which are located in the state of Amazonas, Brazil. The company owns and manages approximately 248,058.94 hectares of Forest Stewardship Council certified forest (PWA 2018). The data for this study was collected during the month of November in 2015 in an area located in Itapiranga $\left(02^{\circ} 75^{\prime} \mathrm{S}\right.$ latitude and $58^{\circ} 47^{\prime} \mathrm{W}$ longitude). The climate in the study area is classified as tropical wet (Af), with average annual precipitation of $2200 \mathrm{~mm}$, without a well-defined dry season, according to the Köppen-Geiger classification system. The annual average temperature is $27^{\circ} \mathrm{C}$ with a relative air humidity of $80 \%$ (Alvares et al. 2013). The forests in the region are classified as tropical rainforest with upland rainforests and lowland rainforests (RADAMBRASIL 1978). The geographical location is shown in Fig. 1.

\subsubsection{Forest Management}

The company uses a polycyclic model (selective logging), based on the CELOS Management System (De Graaf and Van Eldik 2011), with a logging cycle of approximately 30 years. The company uses a treelength logging system, according to which the tree is felled, and then it is bucked into a commercial length and manually processed into logs (exceeding $6 \mathrm{~m}$ length). The logging is subdivided into three operations: felling, pre-skidding and skidding. In the present study, the landing operations were also evaluated to include all activities within the area of forest operations. The landing operations included smaller log landings in the forest that were a part of the active logging operations, and the large log storage yard near the paved highway where logs were transported for storage. The commercial tree volume logged by this company in 2015 was an average of $3.28 \mathrm{~m}^{3}$ per tree, with approximately 40 commercial tree species managed at that time.

\subsubsection{Harvesting Operations}

In a given year, operations are performed during an 8-month period from June to January, with a cessation of operations that coincides with the rainy season in this particular region of the Amazon (off-season). The typical schedule of the workers is 11 consecutive work days followed by a 2 day off period for rest and relaxation. Table 1 outlines the operations, machines used and crew sizes involved in this study.

In the felling operations, crews orient themselves in the forest using maps that indicate the location and species of trees marked for cutting. Prior to felling, marked trees are inspected for hollows located in the tree bole. If no hollows are present, the trees are felled and bucked into a merchantable length or logs with a chainsaw. Afterwards, the pre-skidding crew opens

Table 1 Crew size, sampling size and workers analyzed

\begin{tabular}{|c|c|c|c|c|c|c|}
\hline \multirow{2}{*}{ Parameter } & \multirow{2}{*}{ Felling } & \multirow{2}{*}{ Pre-skidding } & \multirow{2}{*}{ Skidding } & \multicolumn{2}{|c|}{ Landing operations } & \multirow[b]{2}{*}{ Tota } \\
\hline & & & & Log landing & Storage yard & \\
\hline Crews & 10 & 05 & 01 & 01 & 01 & 18 \\
\hline Crew size & 03 & 07 & 06 & 02 & 09 & - \\
\hline Total number of workers & 30 & 35 & 06 & 02 & 09 & 82 \\
\hline Workers involved in study & 18 & 35 & 06 & 02 & 09 & 70 \\
\hline Workdays evaluated in study & 05 & 06 & 05 & 01 & 04 & 21 \\
\hline Duration of workday ** & $\begin{array}{l}10 \text { hours } \\
\text { (07-17h) }\end{array}$ & $\begin{array}{l}11 \text { hours } \\
\text { (07-18h) }\end{array}$ & $\begin{array}{l}13 \text { hours } \\
\text { (07-20h) }\end{array}$ & $\begin{array}{l}13 \text { hours } \\
\text { (06-19h) }\end{array}$ & $\begin{array}{l}12 \text { hours } \\
\text { (06-18h) }\end{array}$ & - \\
\hline Equipment used* & MS & $\mathrm{TE}+\mathrm{GC}$ & SK & $\mathrm{PC}$ & PC & \\
\hline
\end{tabular}

${ }^{*}$ MS - Chainsaw; TE - Crawler tractor; GC - Steel cable winch system; SK - Grapple skidder; PC - Wheel loader

**Workday: working hours +1 hour break (lunch) 
up a previously designated skid trail using a crawler tractor that leads to the location of where the logs are to be extracted. Then the winch line, a cable up to $75 \mathrm{~m}$ long, is manually pulled to the logs from the tractor. The winch line is then attached to a shorter cable, called a choker, that is wrapped around the log. The tractor winch then drags the logs to the skid trails where the topography is not as steep, enabling the operation of skidders. The skidding operation uses a rubbertired grapple skidder to drag the logs to the landings.

The initial step of the landing operations, consist of measurement and an inventory of the logs, removing occasional branches and stacking. Logs are then transported to a large log storage yard near the paved highway, where logs can be stored and shipped at a later time during the off season or adverse weather conditions. As the log storage yard is closer to the logging operations than the mill, this allows for a faster truck turn-around time. The next step of the landing operations occurs at the storage yard, where logs from the forest (log landings) are unloaded from the log trucks by front end articulated wheel loaders, measured, sorted and stacked by species. This enables the company to have quick access to logs, regardless of weather, depending on the mill needs.

\subsection{Data Collection}

The WBGT index (Wet Bulb Globe Temperature) was originally developed for the evaluation of thermal stress in military training (Beshir and Ramsey 1988, Parsons 2001). The WBGT index formula consists of three basic readings for work in an external environment with a solar load that simulates and quantifies the physiological perception or thermal sensation of heat (Parsons 1995, Parsons 2001, Fundacentro 2002, NIOSH 2016), and is presented in Eq. 1.

External environment with solar load:

$$
W B G T=0.7 \cdot T n w+0.2 \cdot T g+0.1 \cdot T a
$$

Where:

$\begin{array}{ll}\text { Tnw } & \text { Natural wet bulb temperature, }{ }^{\circ} \mathrm{C} \\ \mathrm{Tg} & \text { Globe temperature, }{ }^{\circ} \mathrm{C} \\ \mathrm{Ta} & \text { Air temperature, }{ }^{\circ} \mathrm{C}\end{array}$

In this study, a portable and digital unit from Extech Instruments (HT30 model) was used to measure the WBGT index. The digital equipment considers the effect of temperature, humidity and direct sunlight. The »Out « function displays the WBGT value with direct exposure to the sun, with a scale from 0 to $50^{\circ} \mathrm{C}$ (accuracy of $\pm 1^{\circ} \mathrm{C}$ ), relative humidity of 0 to $100 \%$ (accuracy of $\pm 1 \% \mathrm{RH}$ ). This equipment was placed in a vertical position, at the average height of the head of
Table 20 Occupations involved in evaluation of operational cycle and physical workload on forest management operations

\begin{tabular}{|l|c|c|c|}
\hline \multicolumn{1}{|c|}{ Operation } & $\begin{array}{c}\text { Evaluated } \\
\text { Occupation }\end{array}$ & $\begin{array}{c}\text { Physical workload } \\
\mathrm{kcal} / \mathrm{h}\end{array}$ & Classification \\
\hline Felling & Chainsaw operator & 438 & Very heavy \\
\hline Pre-skidding & Choker setter & 350 & Heavy \\
\hline Skidding & Skidder operator & 215 & Moderate \\
\hline Storage yard & Loader operator & 215 & Moderate \\
\hline Log landing & Loader operator & 215 & Moderate \\
\hline
\end{tabular}

Source: Values and classification adapted from Fundacentro (2002) and found at NIOSH (2016)

each forest worker (approximately $1.70 \mathrm{~m}$ ) (Sant'Anna and Malinovski 2002). Within each operation of the process, the workers were chosen primarily based on their greater physical workload and contribution to the operational dynamics, as the environmental conditions were similar for everyone. For example, in the skidding operation, the workload of the skidder operator was analyzed near the worker inside the machine, despite the machine being opened, and assessed due to the essential role in the workday dynamics. The physical workload per occupation is presented in Table 2 .

\subsubsection{Estimation of Time Consumption and Productivity}

For the analysis of the relationship between temperature and work performance, several production variables were evaluated: work cycle time, productivity, rest breaks and mechanical interruption, which were always collected and accompanied by a measurement of WBGT index, simultaneously. This index was used as a reference in the division of operations on partial movements according to the time and motion study described by Barnes (1980). The time consumption, which was recorded in seconds, was measured by the use of a digital chronometer (model ITCD 4000, Instrutemp). Work cycles were evaluated individually, that is, unrelated to working hours. This variable consisted of measuring the individual time for the work cycle of the most important tasks within each operation. For example, during felling, the time taken to cut each tree was measured, always related to WBGT measurements, in a simultaneous way. This stratification was necessary to have a better representation of the dynamics and performance of each specific operation.

In the evaluation of productivity, the analysis was run on an hourly basis; a production value factor was added to obtain a figure close to the real productivity: the volume of felled timber (in $\mathrm{m}^{3}$ ) and the number of logs (for non-felling operations). As such, the productivity 
of timber felling was estimated with Eq. 2, adapted from Emmert (2014):

$$
P=\left(\sum v_{\mathrm{i}}\right) / H_{\mathrm{t}}
$$

Where:

$P \quad$ Productivity, $\mathrm{m}^{3} / \mathrm{SMH}^{-1}$

$v_{\mathrm{i}} \quad$ Individual volume of felled tree, $\mathrm{m}^{3}$

$H_{\mathrm{t}} \quad 1$ hour

For non-felling operations, Eq. 3 uses the same logic, but in another unit of measure, as stated:

$$
P=\left(\sum \log s\right) / H_{\mathrm{t}}
$$

Where:

$P \quad$ Productivity, $\log / \mathrm{SMH}^{-1}$

Logs Number of logs

$H_{\mathrm{t}} \quad 1$ hour

To estimate the efficiency of a worker, the percentage of breaks for rest, rehydrating or eating (excluding lunch time, which is scheduled), were accounted for each hour of work. This is because these variables are strongly correlated to the physical load and heat stress in forestry work (Axelson 1974, Bates et al. 2001, Sant'Anna and Malinovski 2002, Lilley et al. 2002, Christie 2006). These breaks were estimated having as a reference the workers that had the highest physical work load in each operation. It should also be noted that the company does not stipulate when breaks are to occur during the workday, rather they are chosen freely by the employees, except for lunch time which is scheduled (12-13h). Eq. 4 was adapted from Lopes (2007):

Where:

$$
P d=\left(\frac{\sum I_{\mathrm{nd}}}{H_{\mathrm{t}}}\right) \cdot 100
$$

Pd Rest breaks, \%/SMH ${ }^{-1}$

$I_{\text {nd }} \quad$ Interruption for rest, seconds

$H_{\mathrm{t}} \quad 1$ hour, measured in seconds

The interruption time of operations, measured in seconds, was evaluated for preventive or corrective maintenance of machinery and equipment during each hour of work. Eq. 5 was used to calculate the mechanical interruption, which was adapted from Lopes (2007):

Where:

$$
M E=\left(\frac{\sum I_{\mathrm{m}}}{H_{\mathrm{t}}}\right) \cdot 100
$$

$M E \quad$ Percentage of Mechanical Interruption, $\% / \mathrm{SMH}^{-1}$

$I_{\mathrm{m}} \quad$ Mechanical Interruption, seconds

$H_{\mathrm{t}} \quad 1$ hour, measured in seconds

\subsubsection{Workers Profile and Work Safety}

A questionnaire was designed based on personal habits, accounting for medical history and workers' perception, variables that, according to references (Table 10), can facilitate the experience of heat stress. In addition, to contextualize the analysis, it is important to collect the employees' personal information, which allows for estimating the probability of their discomfort to heat, which can affect the occurrence of unsafe actions, behavior and psycho-physiological effects. This personal data was collected through the application of structured questionnaires to all workers from the analyzed groups. Analysis of the questionnaire-related data was carried out by means of descriptive statistics.

One of the simplest methods for detecting the discomfort and fatigue of an employee is to observe their actions and behavior during work activities. The discomfort and stress caused by heat has various psychological characteristics, which are detrimental to the work environment and coworker relationships (Axelson 1974, Ramsey et al. 1983, Slappendel et al. 1993, Wasterlund 1998, Kjellstrom and Crowe 2011).

Therefore, a checklist was used to record unsafe actions and changes in behavior potentially instigated by heat. The objective of this analysis was to verify if the hours with elevated heat during the day, within the study area, could have contributed to the alterations in actions/behaviors, listed in the references (Table 10). This was done to determine which actions were more frequent and which operations had a greater contribution to these detrimental actions or behaviors. Therefore, it was possible to verify where the unsafe actions were located, as well as to see which operations needed the application of improved procedures.

\subsection{Data Analysis}

The analysis by linear regression and multivariate analysis of variance (MANOVA) involved interpreting the results by means of probability ( $p$-value) and coefficient of determination $\left(R^{2}\right)$ values. Probability data were written and interpreted in accordance with a classification table, adapted from IPCC (2010).

The study sought to analyze the depth and the way in which the interactions between environmental variables and operational variables occur in logging operations in the Amazon, and thereby to verify their possible influence on dependent variables in operational dynamics: productivity and rest breaks. The correlation between these two dependent variables was taken into consideration, but the focus was related 
Table 3 Average values of variables per hour during workday

\begin{tabular}{|l|c|c|c|c|c|}
\hline \multirow{2}{*}{ Operation } & \multicolumn{4}{|c|}{ Descriptive statistics - Mean values } \\
\cline { 2 - 6 } & \multicolumn{3}{|c|}{ Dependent variables } & \multicolumn{3}{c|}{ Independent variables } \\
\cline { 2 - 6 } & $\begin{array}{c}\text { Rest breaks } \\
\% / h\end{array}$ & $\begin{array}{c}\text { Productivity } \\
\mathrm{m}^{3} / \mathrm{h}, \text { logs/h or trucks/h }\end{array}$ & $\begin{array}{c}\text { WBGT } \\
{ }^{\circ} \mathrm{C}\end{array}$ & $\begin{array}{c}\text { Mechanical interruption } \\
\% / h\end{array}$ & $\begin{array}{c}\text { Loading trucks } \\
\text { number of trucks }\end{array}$ \\
\hline Felling, $\mathrm{m}^{3}$ & 12.58 & 10.85 & 26.67 & 5.73 & - \\
\hline Pre-skidding, logs & 16.47 & 6.57 & 27.94 & 3.88 & - \\
\hline Skidding, logs & 5.28 & 10.49 & 28.38 & 1.61 & - \\
\hline Storage yard, logs/trucks & 28.84 & 9.55 & 29.32 & 24.67 & - \\
\hline Log landing, trucks & 27.36 & 2.11 & 28.97 & - & - \\
\hline
\end{tabular}

to the variables that affected the efficiency and productivity of the activities, and their interrelations, in order to understand ways to combine labor well-being with higher productivity. The potential effects of the following independent variables were analyzed: WBGT, hour, physical workload, mechanical interruption and loading trucks in the storage yard; the dependent variables was set to productivity and rest breaks. Analysis were performed separately for each operation, using the statistical software Past and R Studio. Initially, the presentation of descriptive statistics for the variables collected (mean values) was done to better understand the analyzed variables and dynamics of work throughout the working hours. Then, the data was subjected to an exploratory analysis through the multivariate statistical method Principal Component Analysis (PCA). This was done in order to verify the behavior of the variables involved and their possible relationships. Following this, the variables were analyzed through Multivariate Analysis of Variance (MANOVA), in which independent and dependent variables were different. Lastly, for the time and motion study a statistical analysis was performed, in which the independent variables were: WBGT, physical work load, single volume (felling) and species (felling). The relationship with time consumption of operational cycle data was evaluated, by using multiple linear regression.

The descriptive analysis of work performance used the hour of the workday as a reference. All quantitative variables analyzed in this study were linked to the variable hour. This was done in order to be able to verify the effects of the possible accumulation of fatigue and changes in the dynamics of work throughout the workday. This linkage to the hour in the day enabled comparisons of the performance of operations on different days for the same hour. Performance variables such as productivity and mechanical interruption were determined from the sum of the units of the variable over an hour. For environmental variables such as WBGT, the hourly value was made from the average of all temperatures measured over an hour of work, always linked to a performance variable. Thus, whenever a tree was felled, WBGT was measured at the site with the aim of obtaining greater accuracy for temperature estimates.

The workers' profile and aspects of safety associated with thermal conditions were analyzed in order to raise hypotheses regarding the influence of other possible variables on performance, such as dynamics and accident risks associated with heat, as well as the relation to psycho-physiological effects and the workers' health conditions.

\section{Results}

\subsection{Work Performance}

For a general understanding of the performance variables and their dynamics during working hours, the average values of each variable analyzed in this

Table 4 Results of Principal Component Analysis (PCA) for all operations

\begin{tabular}{|l|c|c|c|}
\hline \multicolumn{4}{|c|}{ Principle Component Analysis (PCA) - Correlation } \\
\hline \multicolumn{1}{|c|}{ Operation } & Axis & Value & \% Variance \\
\hline \multirow{2}{*}{ Felling } & 1 & 1.80281 & $\mathbf{3 6 . 0 5}$ \\
\cline { 2 - 4 } & 2 & 1.25811 & 25.16 \\
\hline \multirow{2}{*}{ Pre-skidding } & 1 & 2.04645 & $\mathbf{4 0 . 9 2}$ \\
\cline { 2 - 4 } & 2 & 1.48455 & 29.69 \\
\hline \multirow{2}{*}{ Skidding } & 1 & 2.10149 & $\mathbf{4 2 . 0 3}$ \\
\hline \multirow{2}{*}{ Log storage yard } & 2 & 1.17963 & 23.59 \\
\hline \multirow{2}{*}{ Log landing } & 1 & 2.65972 & $\mathbf{4 4 . 3 2}$ \\
\cline { 2 - 4 } & 2 & 1.73461 & 28.91 \\
\hline
\end{tabular}



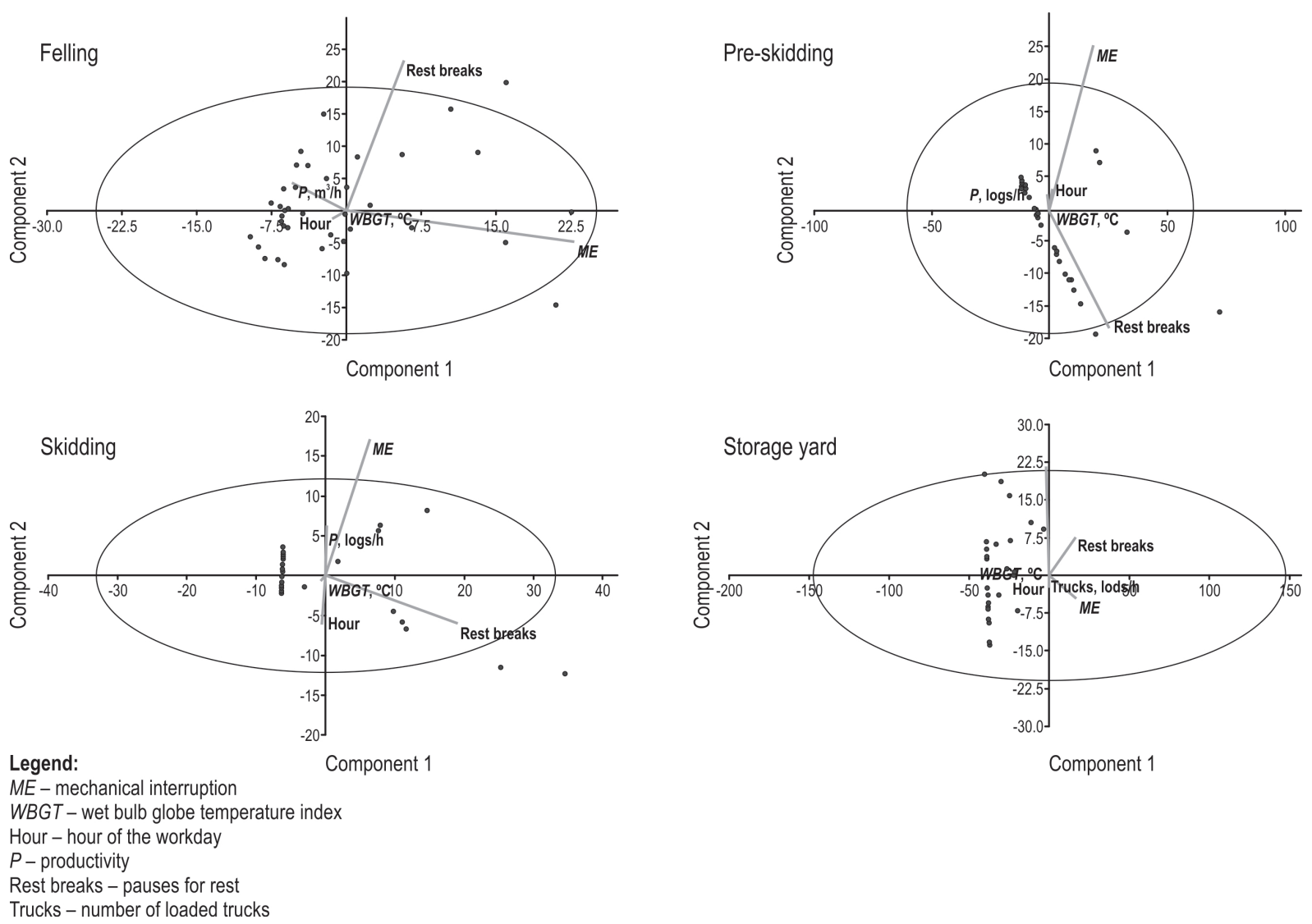

ME - mechanical interruption

WBGT - wet bulb globe temperature index

Hour - hour of the workday

Rest breaks - pauses for rest

Trucks - number of loaded trucks

Fig. 2 Graphical representation of Principal Component Analysis (PCA) with 95\% data ellipses, for operations and variables involved

study were presented (Table 3), with the exception of the hour, which consists of an independent covariate in the statistical analysis.

The Principal Component Analysis (PCA), based on correlation, captured more than $60 \%$ of the varia- tion of the first 2 axes, which was sufficient to explain the exploratory analysis (Table 4).

In the PCA analysis done for all of the examined stages, 3 axes were enough to demonstrate the relevance required in the explanation of the data, which

Table 5 Relationship between variables of each axis of PCA for analyzed operations

\begin{tabular}{|l|c|c|c|c|c|c|c|}
\hline \multicolumn{7}{|c|}{ Principal Component Analysis (PCA) - Significance of variables } \\
\hline \multirow{3}{*}{ Operation } & \multirow{2}{*}{ Axis } & \multicolumn{5}{c|}{ Involved variables } \\
\cline { 3 - 8 } & & Hour & WBGT & Mechanical interruption & Productivity & Rest breaks & Loads \\
\hline \multirow{3}{*}{ Felling } & 1 & $\mathbf{0 . 5 9 0 4}$ & 0.4670 & -0.3801 & $\mathbf{0 . 5 2 0 8}$ & -0.1321 & - \\
\cline { 2 - 8 } & 2 & 0.3372 & 0.5510 & 0.6500 & -0.4000 & 0.0077 & - \\
\hline \multirow{2}{*}{ Pre-skidding } & 1 & 0.3683 & 0.1591 & $\mathbf{0 . 6 3 7 7}$ & -0.2006 & $\mathbf{0 . 6 2 6 1}$ & - \\
\cline { 2 - 8 } & 2 & 0.5759 & 0.6022 & -0.1210 & 0.4971 & -0.2092 & - \\
\hline \multirow{3}{*}{ Skidding } & 1 & -0.4137 & $-\mathbf{0 . 5 1 2 1}$ & $\mathbf{0 . 5 4 3 1}$ & 0.1244 & $\mathbf{0 . 5 0 5 9}$ & - \\
\hline \multirow{3}{*}{ Log storage yard } & 2 & 0.5432 & -0.0568 & 0.1651 & -0.7239 & 0.3875 & - \\
\hline \multirow{2}{*}{ Log landing } & 1 & -0.2986 & -0.1568 & $\mathbf{0 . 5 7 8 8}$ & -0.3051 & $\mathbf{0 . 5 7 9 3}$ & -0.3497 \\
\cline { 2 - 8 } & 2 & 0.4683 & 0.5454 & 0.1707 & -0.5340 & 0.1644 & 0.3764 \\
\cline { 2 - 8 } & 1 & 0.0191 & 0.3482 & - & $\mathbf{0 . 6 6 9 3}$ & $-\mathbf{0 . 6 5 5 9}$ & - \\
\hline
\end{tabular}


Table 6 Analysis of interactions between variables and their effects on productivity and rest breaks using MANOVA

\begin{tabular}{|c|c|c|c|c|c|}
\hline \multicolumn{6}{|c|}{ Multivariate analysis of variance, MANOVA } \\
\hline \multirow{2}{*}{ Operation } & \multirow{2}{*}{ Dependent variables } & \multicolumn{4}{|c|}{ Independent variables, p-value } \\
\hline & & WBGT & Hour & Mechanical interruption & Loading trucks \\
\hline \multirow{2}{*}{ Felling } & Productivity & 0.7192 & 0.1752 & $0.0038 * *$ & - \\
\hline & Rest breaks & 0.5330 & 0.2467 & 0.4908 & - \\
\hline \multirow{2}{*}{ Pre-skidding } & Productivity & 0.7008 & 0.0586 & 0.0545 & - \\
\hline & Rest breaks & 0.8355 & 0.5819 & $0.0000 * * *$ & - \\
\hline \multirow{2}{*}{ Skidding } & Productivity & 0.1001 & $0.0299 *$ & 0.5153 & - \\
\hline & Rest breaks & $0.0394 *$ & 0.1360 & $0.0001 * * *$ & - \\
\hline \multirow{2}{*}{ Storage yard } & Productivity & 0.1699 & 0.7893 & $0.0000 * * *$ & $0.0015 * *$ \\
\hline & Rest breaks & 0.6718 & 0.9238 & $1.2330^{-19 * * *}$ & 0.3535 \\
\hline \multirow{2}{*}{ Log landing } & Productivity & 0.7968 & 0.6772 & - & - \\
\hline & Rest breaks & 0.3091 & 0.1596 & - & - \\
\hline
\end{tabular}

Significant at $5 \% * ; \% * *$ and $0.1 \% * * *$ at significance level.

was approximately $80 \%$. Results showed that Axis 1 presented a similar significance between operations, explaining about $40 \%$ of the interaction between the data and highlighting the mechanical interruption and rest breaks as the main components of the analysis. Axis 2 demonstrated a variation in relevance from $23 \%$ to $37 \%$ between the analyzed operations. The third axis presented a relevance of about $17 \%$. The first two axes represented more than $60 \%$ of the data variability, which is considered satisfactory to explain the data behavior (Field 2005). The results demonstrated that the mechanical interruption and rest breaks were more related to the main axis (PC1), among all stages examined, that is, these were probably the most influential variables, as shown in Fig. 2.

Table 5 indicates the influence of each variable in the variation of the data for each axis.

The results in Table 6 demonstrate the effects of the variables interactions. It shows that the mechanical interruption and rest breaks were more correlated with the principal axis (PC1), with the exception of the felling operation. In the timber felling, the productivity was more related to hour (PC1), presenting a positive correlation of about $50 \%$, or it could be that with the accumulation of hours during the workday the productivity tended to increase. On the axis of mechanical interruption (Axis2), the variable that was more correlated was WBGT at 55\%. Also, the increase in mechanical interruption coincided with the hotter hours of the work day, which could have given a false impression of the rest breaks due to heat. Additionally, these mechanical interruptions were occasional during these hotter hours.

MANOVA was applied to investigate if there was a direct influence on the dependent variables. The sig- nificance of these relations has been expressed by values of probability $(p)$, as shown in Table 6 .

In timber felling operations, the productivity variable demonstrated a virtually certain interaction of mechanical interruption. However, timber felling activities did not require a complete cessation of operations for chainsaw maintenance, but there was a significant effect from breaks for chainsaw: sharpening, mechanical parts and filter replacement and refueling. In the pre-skidding operation, the productivity variable was strongly influenced by hour and mechanical interruption, which demonstrated that this relationship was statistically very likely. The rest breaks were strongly affected by mechanical interruption and these variables showed that the relationship was virtually certain. In the skidding operation, the productivity was mainly affected by the hour, which was a very probable relationship. The rest breaks demonstrated that they were affected by mechanical interruption and WBGT, with a high degree of confidence in this relationship. At the log storage yard, productivity was strongly affected by mechanical interruption, with virtually certain probability of the effect. Besides the downtime of machinery for periodic maintenance, the operator was required to take a rest break until repairs were completed. The variable of WBGT also showed a correlation with machinery interruption. The rest breaks on the landings were influenced predominantly by mechanical interruption, so that this relationship was virtually certain.

\subsubsection{Productivity}

An additional analysis of the productivity was important to document the causes of the highest productivity for various periods, in hours, during the work 
Environmental Thermal Conditions Related to Performance, Dynamics and Safety ... (419-435) K.A. Oliveira-Nascimento et al.

Table 7 Mean values of productivity for all logging operations, estimated at work hour level

\begin{tabular}{|c|c|c|c|c|c|c|}
\hline \multicolumn{7}{|c|}{ Average productivity } \\
\hline \multirow{2}{*}{$\begin{array}{c}\text { Time } \\
6\end{array}$} & \multirow{2}{*}{$\begin{array}{c}\text { Felling } \\
\mathrm{m}^{3} \\
-\end{array}$} & \multirow{2}{*}{$\begin{array}{c}\text { Pre-skidding } \\
\text { logs } \\
-\end{array}$} & \multirow{2}{*}{$\begin{array}{c}\text { Skidding } \\
\text { logs } \\
-\end{array}$} & \multicolumn{2}{|c|}{$\begin{array}{c}\text { Storage yard } \\
\text { logs and loaded/unloaded trucks }\end{array}$} & \multirow{2}{*}{$\begin{array}{c}\text { Log landing } \\
\text { loaded truck } \\
-\end{array}$} \\
\hline & & & & 5.50 & 0.00 & \\
\hline 7 & 6.18 & 3.25 & 11.00 & 15.50 & 0.00 & 1 \\
\hline 8 & 13.09 & 6.17 & 11.40 & 10.75 & 1.25 & 1 \\
\hline 9 & 8.16 & 6.17 & 12.00 & 14.75 & 0.00 & 3 \\
\hline 10 & 10.29 & 6.00 & 10.80 & 5.25 & 1.75 & 3 \\
\hline 11 & 11.69 & 9.17 & 12.40 & 2.50 & 1.00 & 1 \\
\hline 13 & 11.62 & 7.83 & 10.00 & 7.50 & 1.00 & 3 \\
\hline 14 & 12.56 & 8.00 & 7.80 & 16.25 & 1.25 & 3 \\
\hline 15 & 9.13 & 6.33 & 9.60 & 6.00 & 1.75 & 2 \\
\hline 16 & 14.95 & 6.75 & 9.40 & 11.50 & 2.25 & 2 \\
\hline 17 & - & 6.00 & - & - & - & - \\
\hline
\end{tabular}

day. Therefore, solutions were sought to increase productivity throughout the workday. Table 7 shows the average productivity values for every hour worked in the various logging operations. The productivity values were added to define the most productive hours during the workday.

These results demonstrated that the most productive hours in the evaluated logging operations were between 2-5 PM, and 8-10 AM, respectively. These results reflect the positive effects of thermal comfort and that the workers were still well rested between 8 and 10 AM. Nevertheless, the highest productivity of operations occurred between 2 and 3 PM and it could be attributed to the breaks for lunch and rest (midday-1 PM). After the lunch break, workers still took some time for digestion and to return to a suitable work rate. Then they reached their highest level of production between 2 and 3 PM, which is consistent with that hypothesis. The greater productivity achieved between 4 and 5 PM, even at a time of great- er physical fatigue, is likely due to the bonus pay for excess production, which is a financial incentive offered by the company to the employees. Individually, the timber felling operation reached its highest level of productivity between 4 and 5 PM. In both, preskidding and skidding operation, the most productive time was between $11 \mathrm{AM}$ and $12 \mathrm{PM}$. At the log storage yard, the hours of the morning period presented, on average, a higher productivity than after lunch, but the most productive time of the workday was still between 2 and 3 PM.

Fig. 3 shows the relationship between the productivity of operations and the temperature averages for all operations analyzed, throughout the workday.

The graph shown demonstrates a high temperature range in WBGT found during data collection. This is related to the different thermal conditions between the operations, which are greatly influenced by the differences in direct energy due to solar radiation. Thus, the lowest temperatures were found in felling

Table 8 Predictors of operational cycles

\begin{tabular}{|c|c|c|c|c|c|c|}
\hline \multirow{2}{*}{ Operation } & \multicolumn{3}{|c|}{ Vultiple linear regression - Operational cycle } & \multicolumn{3}{c|}{ ANOVA } \\
\cline { 2 - 7 } & Hour & WBGT & Volume & $p$ & $R^{2}$ adjust. \\
\hline Felling & 0.0869 & 0.0675 & $0.0034^{* *}$ & $0.0064^{* *}$ & 0.0678 & 136 \\
\hline Pre-skidding & 0.5098 & 0.2207 & - & 0.2515 & 0.0022 & 344 \\
\hline Skidding & $0.0353^{*}$ & 0.8557 & - & 0.1063 & 0.0119 & 211 \\
\hline Storage yard & $0.0088^{* *}$ & 0.4216 & - & $0.0276^{*}$ & 0.0211 & 245 \\
\hline Log landing & $0.0267^{*}$ & 0.9787 & - & 0.0679 & 0.1962 & 19 \\
\hline
\end{tabular}



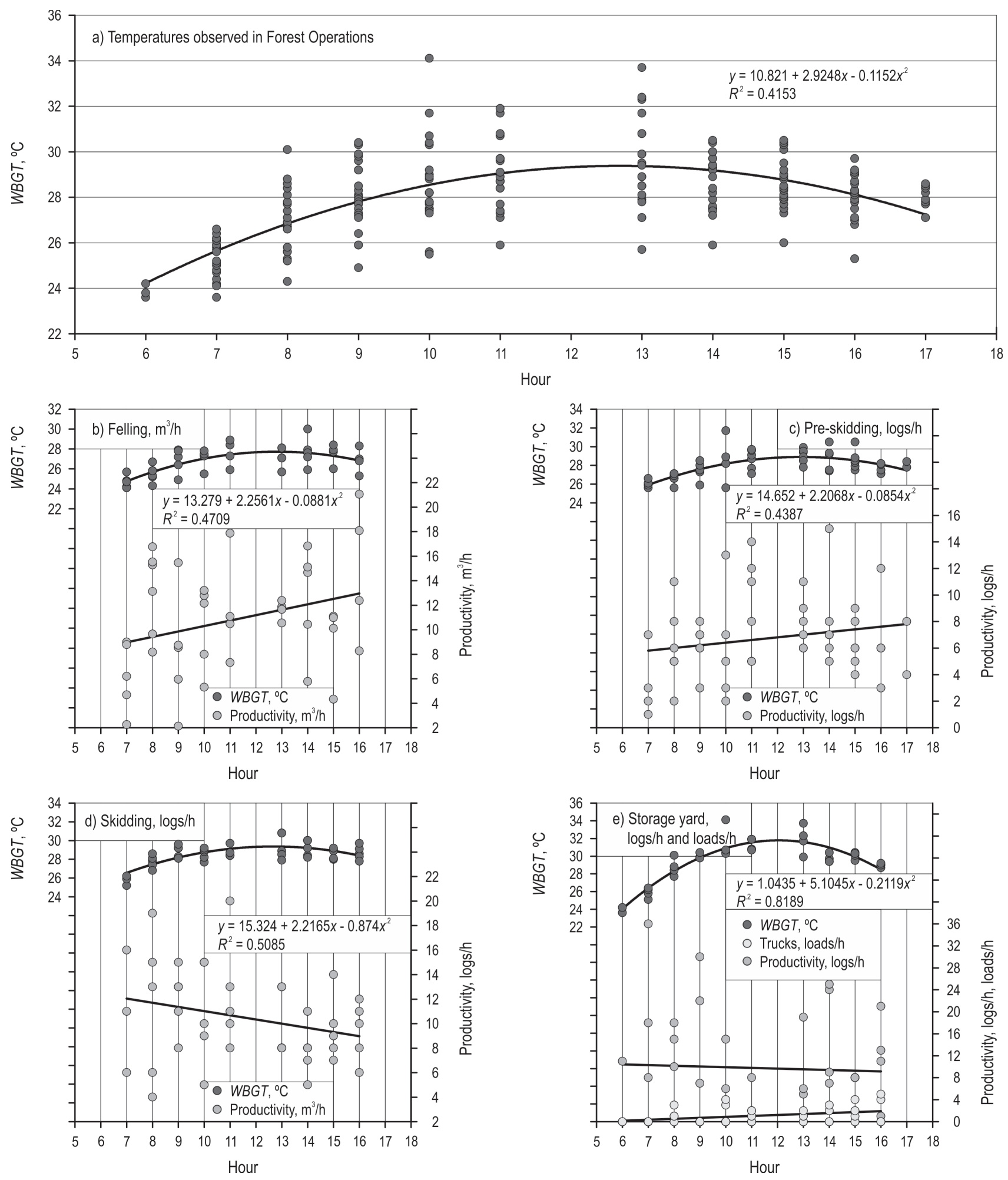

Fig. 3 Graphical representation of WBGT temperatures with results along workday hours and related productivity results for each operation: (3a) polynomial equation adjusted for all temperatures in WBGT $\left({ }^{\circ} \mathrm{C}\right)$ collected in the analyzed operations; (3b-3e) specific WBGT $\left({ }^{\circ} \mathrm{C}\right)$ temperatures observed for each operation and polynomial equation adjusted, related to productivity results and trend lines of productivity along the workday of (b) felling, (c) pre-skidding, (d) skidding and (e) storage yard operation. Observe that the 12-13 h period does not contain data, as it was the scheduled lunch break for all operations in the forest management area 


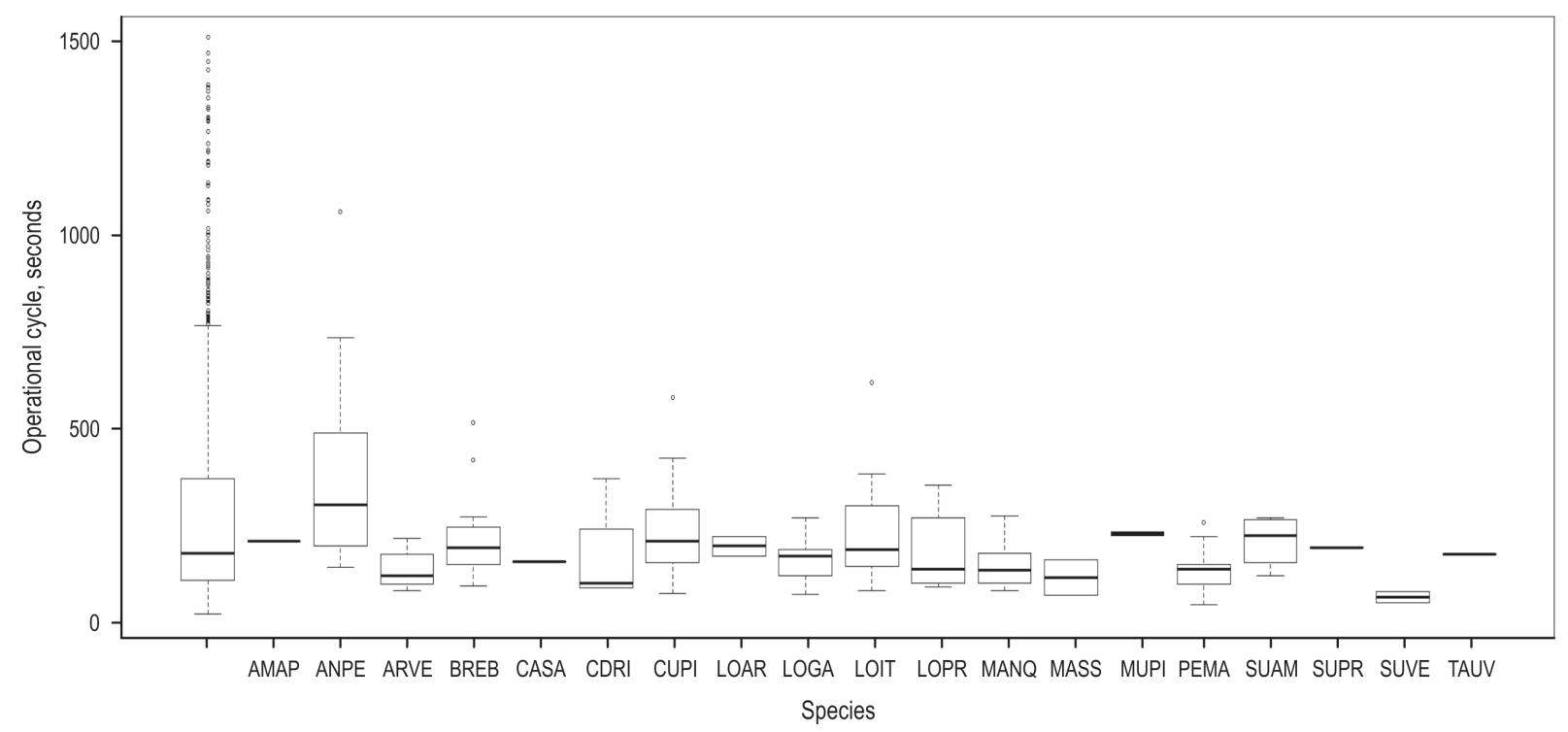

Fig. 4 Effect of species on the average work cycle time in felling operations. Obs: Boxplots with no name result from species unidentified during felling operations

(greatest forest cover) and the highest in the log storage yard (fully open area). Despite this, the variation of measured temperatures was the same throughout the workday.

\subsubsection{Variables Explaining Work Cycle Variation}

To see which variables affected the variation of work cycles, multiple linear regression and analysis of variance (ANOVA) were performed for all of the operations under study. The main results can be seen in Table 8.

The results showed that most of the operations, with the exception of pre-skidding, could be affected at a high probability by at least one of the variables under study. In particular, the variable for tree felling demonstrates with virtual certainty that the volume of the felled tree affects the operational cycle. In the skidding operation, the hour of work was highly significant, and it was very likely that it had an effect on the cycle time. The preference of the skidder operators was to first extract logs closest to the log landing. Then the skidders gradually worked their way back on the skid trails bringing logs further from the landing, which took more time in a work cycle during the time of a work day. Additionally, in felling operations, the tree species that were observed to have an influence on the work cycle duration were related to their morphological characteristics (wood density and presence of a buttress). The species Hymenolobium modestum (Angelim-pedra) abbreviated »ANPE«

Table 9 Workers profile for variables related to the risk of thermal stress at work

\begin{tabular}{|l|c|c|c|c|}
\hline \multirow{2}{*}{\multicolumn{1}{|c|}{ QUESTION }} & \multicolumn{4}{c|}{ \% of workers - Answer (YES) } \\
\cline { 2 - 5 } & Felling & Pre-skidding & Skidding & Landing operations \\
\hline Do you smoke? & 5.6 & 25.7 & 16.7 & 0.0 \\
\hline Do you practice any sports or exercises? & 72.2 & 77.1 & 33.3 & 62.5 \\
\hline If so, do you do it regularly? & 0.0 & 0.0 & 16.7 & 16.7 \\
\hline Do you have any health problem? & 8.3 & 2.9 & 83.3 & 0.0 \\
\hline Do you consume alcoholic beverages? & 72.2 & 71.4 & 100 & 75.0 \\
\hline Do you feel discomfort under heat? & 100 & 100 & 16.7 & 100 \\
\hline Do you feel tiredness during the day? & 100 & 100 & 16.7 & 100 \\
\hline Does the uniform increase the heat discomfort? & 66.7 & 71.4 & 100 & 37.5 \\
\hline Workers evaluated, \% & 60 & 100 & 6 & 80 \\
\hline Total number of workers in the operation & 30 & 35 & & 10 \\
\hline
\end{tabular}


was different in relation to the others, in that it needed a longer mean and median felling time, regardless of the volume (Fig. 4).

\subsection{Workers Profile}

The workers profile for perception and health conditions related to the risk of heat stress at work are shown in Table 9.

The results shown in Table 10 indicate that the workforce felt discomfort due to the heat in the work environment. As for fatigue, most workers reported feeling fatigue during the workday. Most of the workers felt discomfort by wearing the uniform provided by the company, which, despite being lightweight and thin, is made of a synthetic material, which does not facilitate heat loss. Only a small proportion of workers confirmed having health problems and smoking. The majority of smokers worked in the pre-skidding operations, which accounted for $25 \%$ of the pre-skidding crew.

\subsection{Aspects of Work Safety}

The frequency of unsafe actions that occurred during the hottest hours of the day (10 AM - $3 \mathrm{PM})$ is shown in Table 10.
The results indicate that timber felling and preskidding contributed to the highest number of safety violations and unsafe behaviors ( 15 occurrences each), which was potentially related to the thermal discomfort experienced by the workers. Therefore, these operations require more attention and urgency in the implementation of safety measures for the prevention of accidents. The decrease of performance and accuracy in machinery activities (9 observations), attention/ concentration deficit (8) and apathy during the workday (6) were the most frequent, accounting for almost $60 \%$ of all observations.

\section{Discussion}

In regards to work performance and dynamics of the pre-skidding operation within the same area, Emmert (2014) observed a high frequency of mechanical disruption, noting that the use of obsolete machinery (20-30 years old) was the main contributing factor. In the skidding operation, the effect of WBGT was related to the conclusion of Silva (2007), who found that, in Brazil, the use of open cabin machinery is common, which brings with it several environmental hazards to the operators such as heat exposure and dust inhalation. The results demonstrated that the log storage yard

Table 10 Checklist of unsafe actions taken during the hottest hours

\begin{tabular}{|c|c|c|c|c|c|c|}
\hline \multirow[b]{2}{*}{ References } & \multirow[b]{2}{*}{ Unsafe action/behavior } & \multicolumn{5}{|c|}{ Studied Operation (Frequency) } \\
\hline & & Felling & Pre-skidding & Skidding & $\begin{array}{c}\text { Landing } \\
\text { operations }\end{array}$ & Frequency \\
\hline Axelson (1974) & Aggression & 1 & 1 & 0 & 0 & 2 \\
\hline Axelson (1974) & Hysteria & 0 & 0 & 0 & 0 & 0 \\
\hline Axelson (1974) & Apathy & 1 & 2 & 0 & 3 & 6 \\
\hline Axelson (1974) & Changes in social behavior & 1 & 2 & 0 & 1 & 4 \\
\hline $\begin{array}{l}\text { Axelson (1974), Ramsey (1995), } \\
\text { Hancock and Vasmatzidis (2003) }\end{array}$ & Decrease in mental and simple task performance & 3 & 3 & 2 & 1 & 9 \\
\hline Enander (1989) & Changes in the way of doing a task & 1 & 0 & 1 & 0 & 2 \\
\hline $\begin{array}{l}\text { Enander (1989), Hancock and Warm } \\
\text { (1989), Hancock and Vasmatzidis (2003) }\end{array}$ & $\begin{array}{l}\text { Lack of attention/concentration while performing } \\
\text { the work }\end{array}$ & 4 & 3 & 1 & 0 & 8 \\
\hline Hancock and Vasmatzidis (2003) & $\begin{array}{l}\text { Reduction of reaction time to a hazardous } \\
\text { situation }\end{array}$ & 1 & 0 & 0 & 0 & 1 \\
\hline Wyon et. al. (1979) & Understanding verbal communication deficit & 0 & 1 & 0 & 0 & 1 \\
\hline Ramsey (1995) & $\begin{array}{l}\text { Decrease in mental and simple task performance } \\
\text { in machine operation }\end{array}$ & 0 & 2 & 0 & 0 & 2 \\
\hline Vayrynen and Ojanen (1983) & $\begin{array}{l}\text { Removal of personal protective equipment to } \\
\text { alleviate thermal discomfort }\end{array}$ & 3 & 1 & 0 & 0 & 4 \\
\hline TOTAL & & 15 & 15 & 4 & 5 & 39 \\
\hline
\end{tabular}


was likely influenced by the location of this operation, which was located in a large wide-open area, and which also had the highest recorded temperatures due to a high amount of solar energy for most of the day. Axelson (1974) and Wasterlund (1998) noted the decline in labor capacity and adverse effects to the health of workers due to the adverse environmental conditions. The solar radiation brings several serious risks to health (Kjellstrom and Crowe 2011), and it is a factor specific to log landings and storage yards. On the other hand, the cold weather could bring negative effects to the performance of felling that decreased $18.5 \%$ in extreme cold conditions in Northern China (Yongan and Baojun 1998). The authors concluded that below the threshold of $-20^{\circ} \mathrm{C}$, the lower the temperature dropped, the more quickly the operational efficiency decreased.

The mechanical interruption influenced the rest breaks for the majority of the operations, due to the dependence between the machinery and continuity of the operation. The high rates of machine breaks forced the evaluated workers to take rest breaks. The one exception that did not result in rest breaks was when the chainsaw operator performed periodic chainsaw maintenance in the felling operation, such as cleaning the air filter and refueling. The highest percentage of rest breaks in the storage yard was greatly influenced by the high rate of mechanical interruption in the activity caused by regular machinery breakdowns, which forced the operator to take a break until the mechanic finished the maintenance. The voluntary rest breaks observed consisted of several quick breaks of 2 or 3 minutes long for hydration, food or rest per hour, influenced by the additional bonus production payment, that led the workers to return to work activities quickly. Dubé et al. (2016) concluded in their study that a $10 \mathrm{~min}$ long rest break allows the worker to rest and lose part of their accumulated body heat before resuming work. Therefore, considering the results of Dubé et al. (2016), the period of rest breaks in logging is insufficient to eliminate body heat, due to the high relative humidity in Amazon forest, which makes it difficult for the body to lose heat. These results corroborate the 15 minutes minimum period of rest per hour determined by Brazilian regulation (Brasil 1978) to prevent heat stress at work, being also present in other regulations around the world such as NIOSH (2016).

The results of productivity reflect the positive effects of thermal comfort and that the workers were still well rested between 8 and $10 \mathrm{AM}$; similar results were also found by Gandaseca et al. (1997), Silva (2007) and Emmert (2014). The greater productivity achieved between 4 and 5PM, even at a time of greater physical fatigue, was likely due to the bonus payment for ex- cess production, which is a financial incentive offered by the company to its employees (Smith et al. 1985, Lilley et al. 2002). However, Cheta et al. (2018) observed that at the end of the workday, the fatigue was so high that even scheduled rest breaks were not effective in reducing the heart rate. Timber felling operation received the highest bonus payments for production, because it was considered the »bottleneck « of the logging operation, also emphasized by Jourgholami et al. (2013). This is important because, even though the workers reported fatigue, they continued to work at a high pace, which was motivated by the bonus payment for extra production. However, the amount paid is probably insufficient, considering the current conditions of high physical workload, difficult terrain and dense understory conditions (Nascimento et al. 2018), variables that were analyzed by Toupin et al. (2007) and were significant in the variable calculation for bonus production payments. In the pre-skidding stage, the highest productivity was just after the scheduled break of 15 minutes (9 AM) and just before the lunch break, which were motivating factors. At the log storage yard, these results were further supported by the fact that there is a fall in the number of trucks for loading and unloading after the lunch break.

In regards to the work cycle analysis, in the same area as that of the present study, a study conducted by Batista (2008) found that the diameter at breast height was highly correlated to volume and directly influenced felling productivity; this was also concluded by the study of Jourgholami et al. (2013), being consistent with the results found in this study. Axelson (1974) and Wasterlund (1998) noted that the loss of labor capacity was a function of the excessive heat during the workday, even more so when considering the high physical load of the activity (Hagen et al. 1993, Çaliskan and Çaglar 2010, Cheta et al. 2018). Batista (2008) also found a decrease in timber felling productivity with an increase in temperature. The results found for the skidding operation showed an organizational issue expressed by hour, which influenced the analysis, and was also observed by Emmert (2014). Furthermore, the build-up of muscle tension and mental stress of machine operators, tend to generate ergonomic problems and significant fatigue throughout the shift (Attebrant et al. 1997, Kirk et al. 1997, Hagen et al. 1998, Dimou et al. 2020), which led to performance loss throughout the day. Dimou et al. (2020) highlighted that a greater work experience was the main factor for reducing the occurrence of musculoskeletal symptoms. Hagen et al. (1998) and Dimou et al. (2020) suggested job rotations as a measure to relieve mental stress and located musculoskeletal pains. The machinery with an open cabin has 
been shown to bring a number of risks to operators (heat, dust, solar radiation) and this may accelerate the process of fatigue (Silva 2007). Considering the felling operation, the morphological characteristics of some tree species affected the performance (e.g. Hymenolobium modestum), which was related to the density of wood $\left(710 \mathrm{~kg} / \mathrm{m}^{3}\right)$ and the presence of many irregularities at the base of its trunk buttress (IPT 2016), which according to Ferreira et al. (2004) must be removed before felling the tree. Thus, it was highly probable that the features of some logged tree species affected the work cycle time of the chainsaw operator, regardless of their volume. However, Jourgholami et al. (2013) concluded that several other variables influenced the productivity of felling; as it could be difficult to distinguish all the influential factors, it is important to recognize the most significant variables that should be distinguished first (Jourgholami et al. 2013), an approach that was taken by this study.

Taking into consideration the workers profile and safety, previous research noted that several factors contribute to worker discomfort and dehydration such as the ingestion of alcoholic beverages and stress caused by heat (Axelson 1974, Parsons 1995). Indirect$1 y$, health problems (specifically heart diseases) and harmful habits, such as smoking, interfere in the metabolic rate of these workers, who tend to produce more heat during their workday (Axelson 1974, NIOSH 2016). In view of these outside factors, personal aspects of a worker's habits should be considered during the workers selection (Hagen et al. 1993, Sant'Anna and Malinovski 2002, Lilley et al. 2002). Especially, in operations with a greater physical workload (Nascimento et al. 2018, Cheta et al. 2018), where the frequency of deviations and unsafe actions were higher (felling and pre-skidding) in the hottest hours of the day, setting up of scheduled rest breaks and job rotation are ways to minimize the risks of unsafe behavior and accidents. Laschi et al. (2016) analyzed accident records and concluded that felling is definitely the most dangerous activity in forest operations. Even if there is a small loss of production due to rest breaks, the costs associated with accidents and the well-being of a safe work environment are factors that outweigh these losses, results also reported by Borz et al. (2014), who compared the production gains in motor-manual felling by disregarding recommended safety procedures. The authors concluded that the productive and monetary gains are too low to be worth taking risks in a dangerous approach of the operation (Borz et al. 2014). On the other hand, the results found by Montorselli et al. (2010) seem to deny the common sense that safety practice is inversely proportional to productivity. The authors concluded that a higher pro- ductivity depended more on a better organization of the work activities than on higher risk-taking. Lastly, the two most frequently found unsafe actions and behaviors in this study are among the most cited as causes of accidents in forest operations (Axelson 1974, Slappendel et al. 1993, Silva 2007, Machado 2014). Therefore, this information is important for the implementation of effective management practices and the diminishment of accident risks in timber companies, which can be attained through the application of preventive and mitigation measures.

\section{Conclusions}

Mechanical availability was the most influential factor in the performance of logging operations. Thermal conditions and other factors (bonus payments and work dynamics) also showed an influence on work performance. To a lesser degree, there was an influence of safety and workers' physical comfort, resulting in more rest breaks, depending on the operation involved. This influence was observed especially in operations characterized by a higher physical workload (felling and pre-skidding). Moreover, the tree volume had a significant impact on the productivity of the chainsaw operator, which was also influenced by the species. The findings of this study resulted in the implementation of scheduled breaks during the workday, by operation, for the timber company where this research was conducted. This research aimed to improve the well-being of employees, while also increasing operational performance. Lastly, improvements in working conditions such as suitable clothing, a more efficient job rotation and scheduled breaks would lead to a greater well-being and increase labor productivity. These positive effects on safety, quality and performance of overall forest management would help contribute to a greater sustainability of economic development in the Amazon region.

The results provided by this study should be considered in the context that the data was collected during a strong El Niño year (ENSO 2015-2016), which generated heat waves and low air humidity in the Brazilian Amazon, that is, the environmental variables collected in this study generated the worst possible scenarios regarding the risk of heat stress at work for the analyzed period (November). On the other hand, these results also generate opportunities for future research, as these extreme phenomena are increasingly frequent in the region and are closely related to climate change. Therefore, studies like this should be carried out on an annual basis, in years with and without extreme phenomena, in order to compare the influence of thermal conditions on the work and health of forest 
workers, to assess the risk factors, mitigate their effects and to design adaptation measures for outdoor workers related to climate change in the Amazon.

\section{Acknowledgments}

This study was carried out with the support of the Conselho Nacional de Desenvolvimento Científico e Tecnológico (CNPq), National Institute for Amazonian Research (INPA, Brazil), Federal University of Paraná (UFPR, Brazil) and Precious Woods Amazon (PWA), specifically by the efforts from João Cruz and Marcos Souza managers. We would also like to thank the relevant contributions of Prof. Luciano Minette and Prof. Fabiano Emmert to the thesis of the first author, the source for the elaboration of this paper. Lastly, we would like to thank the reviewers of the paper, who added important contributions to the improvement of this research.

\section{References}

Ahmed, S.E., Ewers, R.M., 2012: Spatial Pattern of Standing Timber Value across the Brazilian Amazon. PLOS ONE 7(5): e36099. https://doi.org/10.1371/journal.pone.0036099

Alvares, C.A., Stape, J.L., Sentelhas, P.C., Gonçalves, J.L.M., Sparovek, G., 2013: Köppen's climate classification map for Brazil. Meteorologische Zeitschrift 22(6): 711-728. https://doi. org/10.1127/0941-2948/2013/0507

Attebrant, M., Winkel, J., Mathiassen S.E., Kjellberg, A., 1997: Shoulder-arm muscle load and performance during control operation in forestry machines: effects of changing to a new arm rest lever and boom control system. Applied Ergonomics 28(2): 85-97. https://doi.org/10.1016/s0003-6870(96)00050-6

Axelson, O., 1974: Heat Stress in Forest Work. Food and Agriculture Organization of United Nations, Rome, 1-31.

Barnes, R.M., 1980: Motion and time study: Design and measurement of work ( $7^{\text {th }}$ Ed.). New York: John Wiley and Sons, $1-704$.

Bates, G., Parker, R., Ashby, L., Bentley, T., 2001: Fluid intake and hydration status of forest workers - A preliminary investigation. International Journal of Forest Engineering 12(2): 27-32. https://doi.org/10.1080/14942119.2001.10702443

Batista, H.L.D.P., 2008: Estudo de tempo e rendimento da motosserra considerando fatores ergonômicos numa exploração florestal na Amazônia Central. Dissertação de mestrado. Instituto Nacional de Pesquisas da Amazônia/Universidade Federal do Amazonas. Inpa/Ufam, Manaus, Amazonas, 1-105.

Beshir, M.Y., Ramsey, J.D., 1988: Heat stress indices: A review paper. International Journal of Industrial Ergonomics 3(2): 89-102. https://doi.org/10.1016/0169-8141(88)90012-1

BIONTE, 1997: Relatório final do projeto BIONTE (Biomassa e nutrientes na floresta tropical). INPA/DFID, Manaus, 1-345.

Borz, S.A., Ignea, G., Popa, B., Sparchez, G., Iordache, E., 2015: Estimating time consumption and productivity of roundwood skidding in group shelterwood system - a case study in a broad leaved mixed stand located in reduced accessibility conditions. Croat. j. for. eng. 36(1): 137-146.

Borz, S.A., Ignea, G., Vasilescu, M.M., 2014: Small gains in wood recovery rate when disobeying the recommended motor-manual tree felling procedures: another reason to use the proper technical prescriptions. Bioresources 9(4): 6938-6949.

Brasil, 1978: Norma Regulamentadora № 15: Atividades e operações Insalubres. Ministério do Trabalho e Emprego.

Çaliskan, E., Çaglar, S., 2010: An assessment of physiological workload of forest workers in felling operations. African Journal of Biotechnology 9(35): 5651-5658.

Cheța, M., Marcu, M.V., Borz, S.A., 2018: Workload, exposure to noise and risk of musculoskeletal disorders: A case study of motor-manual tree felling and processing in poplar clear cuts. Forests 9(6): 300. https://doi.org/10.3390/\$9060300

Christie, C.J., 2006: A field investigation of physical workloads imposed on harvesters in South African forestry. Dissertation, Rhodes University, Grahamstown, South Africa, 1-179.

De Graaf, N.R., Eldik, T.V., 2011: Precious woods, Brazil. In: Sustainable management of tropical rainforests: The CELOS management system, Werger, MJA. (ed.). Tropenbos International, Paramaribo, 187-199.

Dimou, V., Malesios, C., Pispa, S., 2020: Assessing forestryrelated musculoskeletal symptoms in specific body areas. International Journal of Forest Engineering 31(3): 233-241. https://doi.org/10.1080/14942119.2020.1789393

Dubé, P.A., Imbeau, D., Dubeau, D., Lebel, L., Kolus, A., 2016: Removing the thermal component from heart rate provides an accurate VO2 estimation in forest work. Applied Ergonomics 54: 148-157. https://doi.org/10.1016/j.apergo.2015.12.005

Emmert, F., 2014: Combinação de dados de campo e métodos computacionais para o planejamento da exploração florestal na Amazônia. Tese De Doutorado, Universidade De Brasília, 1-190.

Enander, A.E., 1989: Effects of thermal stress on human performance. Scandinavian Journal of Work, Environment \& Health 15: 27-33.

Extech Instruments, 2015: Heat stress WBGT meter ht-30. Product datasheet.

Ferreira, G.C., Gomes, J.I., Hopkins, M.J.G., 2004: Estudo anatômico das espécies de Leguminosae comercializadas no estado do Pará como »angelim «. Acta Amazonica 34(3): 387398. https://doi.org/10.1590/S0044-59672004000300005

Field, A., 2005: Discovering statistics using SPSS. $2^{\text {nd }}$ edition, Sage, London, 1-779.

Fundacentro, 2002: Norma De Higiene Ocupacional 06: Avaliação da Exposição Ocupacional Ao Calor. Fundação Jorge Duprat Figueiredo de Segurança e Medicina do Trabalho. Ministério do Trabalho e Emprego.

Gandaseca, S., Yoshimura, T., Yamamoto, T., Kanzaki, K. ,1997: Working time design for industrial forest plantations in East Kalimantan. Journal of Forest Research 2(1): 21-24. https://doi. org/10.1007/BF02348258

Hagen, K.B., Magnus, P., Vetlesen, K., 1998: Neck/shoulder and low-back disorders in the forestry industry: elationship to 
work tasks and perceived psychosocial job stress. Ergonomics 41(10): 1510-1518. https://doi.org/10.1080/001401398186243

Hagen, K.B., Vik, T., Myhr, N.E., Opsahl, P.A., Harms-Ringdahl, K., 1993: Physical workload perceived exertion and output of cut wood as related to age in motor-manual felling. Ergonomics 36(5): 479-488. https://doi.org/10.1080/ 00140139308967906

Hancock, P.A., Vasmatzidis, I., 2003: Effects of heat stress on cognitive performance: the current state of knowledge. International Journal of Hyperthermia 19(3): 355-372. https://doi. org/10.1080/0265673021000054630

Hancock, P.A., Warm, J.S., 1989: A dynamic model of stress and sustained attention. Human Factors 31(5): 519-537. https:// doi.org/10.1177/001872088903100503

Higuchi, N., Santos, J., Lima, A.J.N., Higuchi, F.G., Silva, R.P., Souza, C.A.S., Pinto, F.R., 2010: Perspectivas do manejo florestal sustentável para a Amazônia brasileira. Hiléia 8: 78-93.

Iida, I., 1990: Ergonomia: Projeto e Produção. 1ª Ed. São Paulo: Edgard Blücher, $614 \mathrm{p}$.

INMET, 2016: Banco de dados meteorológicos para ensino e pesquisa. Instituto Nacional de Meteorologia.

IPCC, 2010: Guidance note for lead authors of the IPCC fifth assessment report on consistent treatment of uncertainties. In: IPCC cross-working group meeting on consistent treatment of uncertainties. Inter-Governmental Panel on Climate Change Jasper Ridge. CA, USA.

IPT, 2016: Instituto De Pesquisas Tecnológicas.

Jiménez-Muñoz, J.C., Sobrino, J.A., Mattar, C., Malhi, Y., 2013: Spatial and temporal patterns of the recent warming of the Amazon Forest. Journal of Geophysical Research: Atmospheres 118(11): 5204-5215. https://doi.org/10.1002/jgrd.50456 Jourgholami, M., Majnounian, B., Zargham, N., 2013: Performance, capability and costs of motor-manual tree felling in Hyrcanian hardwood forest. Croat. j. for. eng. 34(2): 283-293.

Kirk, P.M., Byers, J.S., Parker, R.J., Sullman, M.J.M., 1997: Mechanisation developments within the New Zealand forest industry: The human factors. Journal Forest Engineering 8(1): 75-80.

Kjellstrom, T., Crowe, J., 2011: Climate change, workplace heat exposure, and occupational health and productivity in Central America. International Journal of Occupational and Environmental Health 17(3):270-281. https://doi.org/ 10.1179/107735211799041931

Laschi, A., Marchi, E., Foderi, C., Neri, F., 2016: Identifying causes, dynamics and consequences of work accidents in forest operations in an alpine context. Safety Science 89: 28-35. https://doi.org/10.1016/j.ssci.2016.05.017

Lilley, R., Feyer, A.M., Kirk, P., Gander, P.A., 2002: Survey of forest workers in New Zealand - Do hours of work, rest and recovery play a role in accidents and injury? Journal of Safety Research 33(1): 53-71. https://doi.org/10.1016/S00224375(02)00003-8

Lopes, S.E., 2007: Análise técnica e econômica de um sistema de colheita florestal. Tese de doutorado. Universidade Federal De Viçosa, UFV, 124 p.
Machado, C.C., 2014: Colheita Florestal. 3ª Ed. Editora Viçosa, 543 p.

Montorselli, N.B., Lombardini, C., Magagnotti, N., Marchi, E., Neri, F., Picchi, G., Spinelli, R., 2010: Relating safety, productivity and company type for motor-manual logging operations in the Italian Alps. Accident Anal. Prev. 42(6): 2013-2017. https://doi.org/10.1016/j.aap.2010.06.011

Nascimento, K.A.O., Emmert, F., Robert, R.C.G., 2017: Exposição ocupacional ao calor na exploração florestal: regime de pausas da norma brasileira versus regime natural. BIOFIX Scientific Journal 2(Especial I MECFOR): 16-22. https://doi. org/10.5380/biofix.v2i0.56341

Nascimento, K.A.O., Higuchi, N., Emmert, F., 2018: Frequência cardíaca para estimativas da carga física de trabalho na exploração florestal. BIOFIX Scientific Journal 3(1): 210-215. https:// doi.org/10.5380/biofix.v3i1.58654

NIOSH, 2016: Criteria for a recommended standard: Occupational exposure to heat and hot environments. Revised criteria. By: Jacklitsch, B., Williams, W.J., Musolin, K., Coca, A., Kim, J.H., Turner, N., Department of Health and Human Services. Centers for Disease Control and Prevention. National Institute for Occupational Safety and Health.

Parsons, K.C., 1995: International heat stress standards: A review. Ergonomics 38(1): 6-22. https://doi.org/10.1080/ 00140139508925081

Parsons, K.C., 2001: The estimation of metabolic heat for use in the assessment of thermal comfort. In Proceedings of the NCEUB conference - »Moving Thermal Comfort Standards into the 21st Century«, Windsor, UK, 301-308 p.

PWA, 2018: Precious Woods Amazon. Public Overview: Sustainable Forest Management. Itacoatiara, Brasil.

RADAMBRASIL, 1978: Projeto RADAMBRASIL. Levantamento dos recursos naturais. Volume 18. Folha as. 20 Manaus. Geologia, geomorfologia, pedologia, vegetação e uso potencial da terra. Rio de Janeiro. 628 p. Ministério das Minas e Energia.

Ramsey, J.D., 1995: Task performance in heat: A review. Ergonomics 38(1): 154-165. https://doi.org/10.1080/ 00140139508925092

Ramsey, J.D., Burford, C.L., Beshir, M.Y., Jensen, R.C., 1983: Effects of workplace thermal conditions on safe work behavior. Journal of Safety Research 14(3): 105-114. https://doi. org/10.1016/0022-4375(83)90021-X

Sant'anna, C.M., Malinovski, J.R., 2002: Uso da análise multivariada no estudo de fatores humanos em operadores de motosserra. Cerne 8(2): 98-104.

Silva, E.P., 2007: Avaliação dos fatores ergonômicos em operações de extração florestal em terrenos montanhosos na região de Guanhães. MG. Dissertação de Mestrado. Universidade Federal de Viçosa, UFV, Viçosa, Minas Gerais, 108 p.

Slappendel, C., Laird, I., Kawachi, I., Marshall, S., Cryer, C., 1993: Factors affecting work-related injury among forestry workers: A review. Journal of Safety Research 24(1): 19-32. https://doi.org/10.1016/0022-4375(93)90048-R

Smith, L.A., Wilson, G.D., Sirois, D.L., 1985: Heart-rate response to forest harvesting work in the South-Eastern United States during summer. Ergonomics 28(4): 655-664. https://doi. org/ 10.1080/00140138508963179 
Strand, J., Soares-Filho, B., Costa, M.H., Oliveira, U., Ribeiro, S.C., Pires, G.F., Oliveira, A., Rajão, R., May, P., van der Hoff, R., Siikamäki, J., da Motta, R.S., Toman, M., 2018: Spatially explicit valuation of the Brazilian Amazon Forest's Ecosystem Services. Nature Sustainability 1(11): 657-664. https://doi. org/10.1038/s41893-018-0175-0

Toupin, D., LeBel, L., Dubeau, D., Imbeau, D., Bouthillier, L., 2007: Measuring the productivity and physical workload of brushcutters within the context of a production-based pay system. Forest Policy and Economics 9(8): 1046-1055. https:// doi.org/10.1016/j.forpol.2006.10.001

Vaèyrynen, S., Ojanen, K., 1983: The protection of loggers' heads and eyes in forestry work. Journal of Occupational Ac- cidents 5(2): 81-88. https://doi.org/10.1016/0376-6349(83) 90013-5

Wasterlund, D.S., 1998: A review of heat stress research with application to forestry. Applied Ergonomics 29(3): 179-183. https://doi.org/10.1016/S0003-6870(97)00063-X

Wyon, D.P., Andersen, I., Lundqvist, G.R., 1979: The effects of moderate heat stress on mental performance. Scandinavian Journal of Work, Environment and Health 5(4): 352-361. https://doi.org/ 10.5271/sjweh.2646

Yongan, W., Baojun, J., 1998: Effects of low temperature on operation efficiency of tree-felling by chainsaws in north China. Journal of Forestry Research 9(1): 57-58. https://doi. org/10.1007/BF02856458 of the Creative Commons Attribution (CC BY) license (http://creativecommons.org/licenses/by/4.0/).

Received: April 08, 2020

Accepted: October 26, 2020
Authors' addresses:

Prof. Kauê Augusto Oliveira Nascimento, MSc * e-mail: kaue.a.o.nascimento23@gmail.com Prof. Renato Cesar Gonçalves Robert, PhD e-mail: renatorobert@hotmail.com Prof. Julio Eduardo Arce, PhD e-mail: jarce@ufpr.br Federal University of Paraná (UFPR) Wood Supply and Forest Mechanization Lab (LAMEC) Prefeito Lothário Meissner Avenue, 632 80210-170 Jardim Botânico Curitiba - PR BRAZIL

Prof. Niro Higuchi, PhD e-mail: higuchi.niro@gmail.com Daniel DeArmond, MSc e-mail: daniel.dearmond.lmf@gmail.com National Institute for Amazonian Research (INPA) Laboratory of Forest Management (LMF) André Araújo Avenue, 2936, Campus III. Petrópolis Manaus-AM

BRAZIL

Prof. João Paulo Fidalgo Carvalho, PhD e-mail: jpfc@utad.pt University of Trás os Montes and Alto Douro (UTAD)

School of Agrarian and Veterinary Sciences (ECAV)

Polo II. Quinta de Prados

Vila Real 5000-801

PORTUGAL

* Corresponding author 